\title{
EFFECTS AND RISKS IN BUILDING OF PEDESTRIAN AND BICYCLE UNDERPASSES AND OVERPASSES IN URBAN AREAS
}

\author{
Petia Sotirova \\ University of Architecture, Civil Engineering and Geodesy, \\ 1, Hristo Smirnenski Blvd, 1164 Sofia, Bulgaria, \\ e-mail: petiasotirova@mail.bg
}

\begin{abstract}
The paper considers the role of pedestrian and bicycle underpasses and bridges in the context of contemporary requirements for sustainable urban mobility. The factors influencing the type selection, planning and construction are analyzed. Underground and overhead alternatives are compared. Conclusions regarding construction benefits and risks are made. The spatial influence of pedestrian and bicycle bridges in a specific urban context is considered.

Keywords: pedestrian and bicycle underpasses and bridges, sustainable urban mobility, transport policy, urban environment.
\end{abstract}

\section{INTRODUCTION}

One of the current problems of the environment for sustainable urban mobility is the study of the necessity and the possibilities of building modern combined pedestrian and bicycle passages, in compliance with all current requirements for an accessible environment. Their role is indisputable as a necessary element of the system of non-motorized traffic with significant spatial presence in the cities.

The present paper discusses the urban preconditions, functional, spatial, architectural and artistic requirements for underground and terrestrial pedestrian and bicycle facilities. On the basis of analysis and assessment of the individual types, conclusions are drawn about the effects and risks of their construction in the modern urban environment.

\section{URBAN FACTORS AND CONDITIONS FOR BUILDING PEDESTRIAN AND BICYCLE FACILITIES ON TWO LEVELS}

With a proven need for their construction, modern pedestrian and bicycle facilities on two levels (bridges, tunnels, underpasses and overpasses) realize

DOI: 10.7546/EngSci.LVI.19.02.06

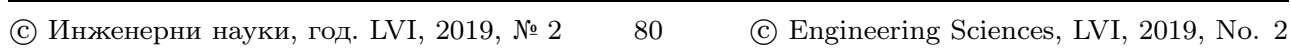


the necessary connections in the pedestrian and bicycle system and directly influence its comfort, connectivity and beneficial impact on the environment for non-motorized mobility in cities. They should be built in parallel and interlinked with an upgrading of the transport infrastructure, which allows the basic quality requirements for non-motorized traffic to be met:

- Efficiency - a direct route with the least possible horizontal barriers and unacceptable detours that extend the distance and time and reduce the attractiveness of the pedestrian and bicycle route;

- Safety - one-level solutions do not sufficiently guarantee crossing safety;

- Continuity - connected network of main routes with access to a large number of premises;

- Attractiveness - a noticeable, pleasant and easy-to-navigate route.

The diversity of pedestrian and bicycle facilities does not allow the establishment of common and unambiguous criteria for their analysis. The main sign of differentiation between them is the type of obstacle (barrier). It determines the functional and spatial requirements of the facility, the access to it and the necessary resources for its optimal functioning.

Barriers to non-motorized traffic are of two main types: physical obstacles such as large water areas, rivers, canals and railroads; dangerous roads and junctions. These include some circular traffic or traffic lights intersections, where division into levels is determined by recommendations for the direct passing and safety of non-motorized traffic. The type of the facility depends both on the type of obstacle and the way it is overcome, as well as on the importance of the pedestrian and bicycle route in the crossing area, Fig. 1. In the case of physical obstacles and traffic arteries on a lower level, different types of bridges are built depending on the hierarchy of each type of traffic: combined for motorized and non-motorized; combined pedestrian and bicycle; only pedestrian. The main ground-level transport arteries are intersected by pedestrians and cyclists through traffic light regulated crossroads and when necessary, on two levels - through tunnels, underpasses and overpasses.

In any case, a serious transport communication, economic and space-based justification is required for the construction of a bridge, overpass, tunnel or underpass for non-motorized traffic. The effect on its comfort is not unambiguous due to the specific access conditions and the different spatial impacts of the individual facilities. It is a well-known and unequivocal recommendation that pedestrians and main bicycle paths in cities should move on terrain level. Therefore, roads bridges close to the level of the adjacent terrain naturally located on their main have a proven beneficial effect in contrast to overpasses that are often difficult to reach and not always in harmony with the surroundings.

(c) Инженерни науки, год. LVI, 2019, № 2 81 $\quad$ (c) Engineering Sciences, LVI, 2019, No. 2 


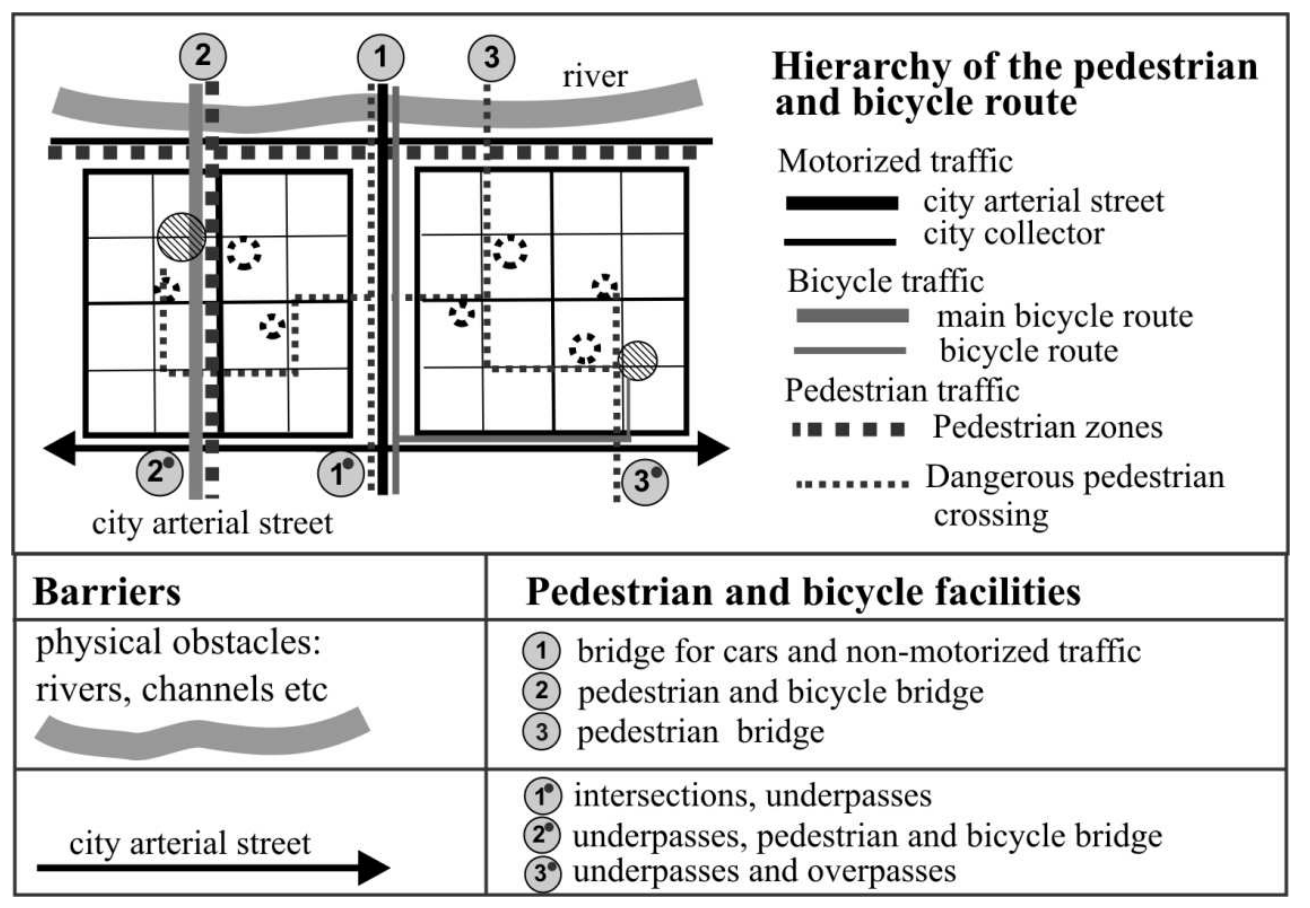

Fig. 1. Types of facilities in relation to the type of obstacles and the hierarchy of the traffic-pedestrian connections

The recommended requirements for the construction of a pedestrian underpass or overpass in Bulgaria are regulated by the Bulgarian legislation from 2004 [1]. They are related to the intensity of the pedestrian traffic, the class of the intersected street and the registered road traffic accidents with pedestrians. Separation of levels is mandatory for streets of Class I, crossing of distinct pedestrian zones and streets of Class I and II streets, intersection of intensive pedestrian ( $>2000$ Persons/hour) with very wide streets (four or more lanes in both directions), places with more than 3 traffic accidents for one year or over seven accidents for three years. The location of pedestrian underpasses and walkways is determined depending on the directions of the main pedestrian streams, the proximity of attraction sites and the points of public transport stops for passenger transport. The advisable distance between them is in the range of 300 to $500 \mathrm{~m}$.

Bicycle crossing on different levels is recommended at the busiest intersections of fast and heavy traffic roads. According to established international technical standards [2], it is necessary in the following general situations:

$\begin{array}{lll}\text { (c) Инженерни науки, год. LVI, 2019, № } 2 & 82 & \text { (c) Engineering Sciences, LVI, 2019, No. } 2\end{array}$ 
- A cycle link that crosses a very fast main road (speed above $70 \mathrm{~km} / \mathrm{h}$ );

- A cycle link on a busy local access road (over 500 vehicles/hour), in case of highly used local or main bicycle route that crosses a busy main road (over 1500 vehicles/hour);

- A cycle link on a busy distributor road (over 1000 vehicles/hour) that crosses a very busy distributor road (over 1500 vehicles/hour).

\section{COMPARATIVE ANALYSIS, ADVANTAGES AND DISADVANTAGES OF DIFFERENT TYPE OF PEDESTRIAN AND BICYCLE FACILITIES ON TWO LEVELS}

The main factors for choosing the type of facility are the communication situation, the degree of construction of the adjoining city region, the specific spatial and architectural - artistic requirements, the relief, the possible technical constraints. The importance of each factor depends on the particular urban context. For example, the social security argument is less important in an active urban area than in an isolated, unbuilt or sparsely populated area. A major advantage of underground facilities is the lower height of tunnels and underpasses, which in turn host different commerces. Walking and cycling tunnels are usually built under main transport routes in less developed and suburban areas. Underpasses are built at dangerous urban junctions with intense pedestrian traffic and are preferably combined with commercial, service and public transport stops, making them largely unattractive to cyclists. The attached Table 1 summarizes the advantages and disadvantages of bridges and tunnels for cyclists based on a PRESTO Grade Separation Consortium classifications [2], according to certain criteria, which in most cases are also valid for pedestrians.

\section{REQUIREMENTS TO PEDESTRIAN AND CYCLIST FACILITIES}

\subsection{Functional and regulatory requirements}

Basic requirements for pedestrian and cyclist tunnels are: a straight road without bends; open, uninterrupted, good visibility entrances; visible exits as soon as you enter; high-quality vandal-proof lighting, possibly embedded in the walls and ceiling; pedestrian pavement at least on one side with a minimum width of $1 \mathrm{~m}$. Recommendation at the entrances is to avoid high vegetation and elements that create the possibility of concealment. Beneficial effects are

(c) Инженерни науки, год. LVI, 2019, № 283 (c) Engineering Sciences, LVI, 2019, No. 2 
TABLE 1. Advantages and disadvantages of bridges and tunnels for cyclists

\begin{tabular}{|c|c|c|}
\hline Criteria & Bridge & Tunnel \\
\hline Personal Safety & $\begin{array}{l}(+) \text { High, open space } \\
\text { with good visibility }\end{array}$ & $\begin{array}{l}\text { (-) Feeling insecure in a closed } \\
\text { space without visibility and } \\
\text { public control }\end{array}$ \\
\hline Comfort & $\begin{array}{l}(-) \text { Longer ramps } \\
\text { Exposed to rain, wind } \\
\text { Possible aerophobia } \\
\text { in long and narrow } \\
\text { bridges }\end{array}$ & $\begin{array}{l}\text { (+) Shorter ramps. Protected } \\
\text { from atmospheric conditions } \\
\text { Possible claustrophobia in a } \\
\text { long, narrow and winding tun- } \\
\text { nel }\end{array}$ \\
\hline $\begin{array}{l}\text { Urban space } \\
\text { Urban and archi- } \\
\text { tectural potential }\end{array}$ & $\begin{array}{l}(+) \text { High potential } \\
\text { Strong visual impact }\end{array}$ & $\begin{array}{l}\text { (-) Limited potential and vi- } \\
\text { sual impact }\end{array}$ \\
\hline Cost & $(+)$ Mostly cheaper & $\begin{array}{l}(-) \text { More expensive due to } \\
\text { groundwater and utilities pip- } \\
\text { ing }\end{array}$ \\
\hline \multicolumn{3}{|c|}{ Recommended technical specifications } \\
\hline Width & $3.5 \mathrm{~m}(3 \mathrm{~m}$ bike lane $)$ & $3.5 \mathrm{~m}(3 \mathrm{~m}$ bike lane $)$ \\
\hline Height & $\begin{array}{l}4.5 \mathrm{~m} \text { underneath, } \\
\text { handrail }>1.2 \mathrm{~m}\end{array}$ & $2.5 \mathrm{~m}$ \\
\hline Maximum slope & $5 \%$ & $5 \%$ \\
\hline
\end{tabular}

the upwardly extending walls and the possibility of natural light penetration. Walking subways in intensive urban areas are integrated urban public spaces, they are the subject of an interdisciplinary study for the best possible access for cyclists and people with mobility disabilities.

Essential requirements for pedestrian and bicycle bridges and footbridges can be summarized as follows: safety, structural stability, vibration avoidance, wheelchair comfort and pushchairs, stable railings, stable and non-slippery flooring, possibilities for easy control and maintenance of the structure and cleaning of the glazing, sun protection, good ventilation and protection of birds from collisions with glass walls with fully glazed walls and roof.

The length of the pedestrian bridges depends on the obstacle and the height of the pedestrian bridges must allow traffic underneath to pass. The width is relatively small and depends on the intensity of pedestrian flows: minimum $1.2 \mathrm{~m}$, recommended for free two-way passage $-2 \mathrm{~m}$. Modern combined bridges for pedestrians and cyclists have a minimum width of $3.5 \mathrm{~m}$ and a clear line that prevents pedestrians from entering the ride of fast-moving cyclists.

(c) Инженерни науки, год. LVI, 2019, № 284 (c) Engineering Sciences, LVI, 2019, No. 2 
A key role for the harmonious entry of overground pedestrian and bicycle facilities into the adjoining environment is played by their height with respect to the adjacent terrain and ways to overcome the required climb of at least 6 $m$ (including bridge construction), which ensures unimpeded transit of traffic including freight. In the specialized technical literature [3] three main options are explored: the main road and the embankment in the approaches to the bridge, Fig. 2(a); semi-partial excavation of the transport artery and partial lifting of the bridge, Fig. 2(b); fully excavated artery with a bridge at the level of the adjacent terrain, Fig. 2(c). The three options have different spatial impacts and require different spatial resources to access the main bridge level. The length of the ramps for access to the bridge is determined by the maximum permissible slope for cyclists and the requirements for an accessible environment. Their main variants are applied depending on the context and have specific advantages and disadvantages. From environmental and spatial considerations in intensive urban areas, it is recommended to reduce the level on which transit traffic is passing, regardless of the high construction value and the poor visibility for the drivers.

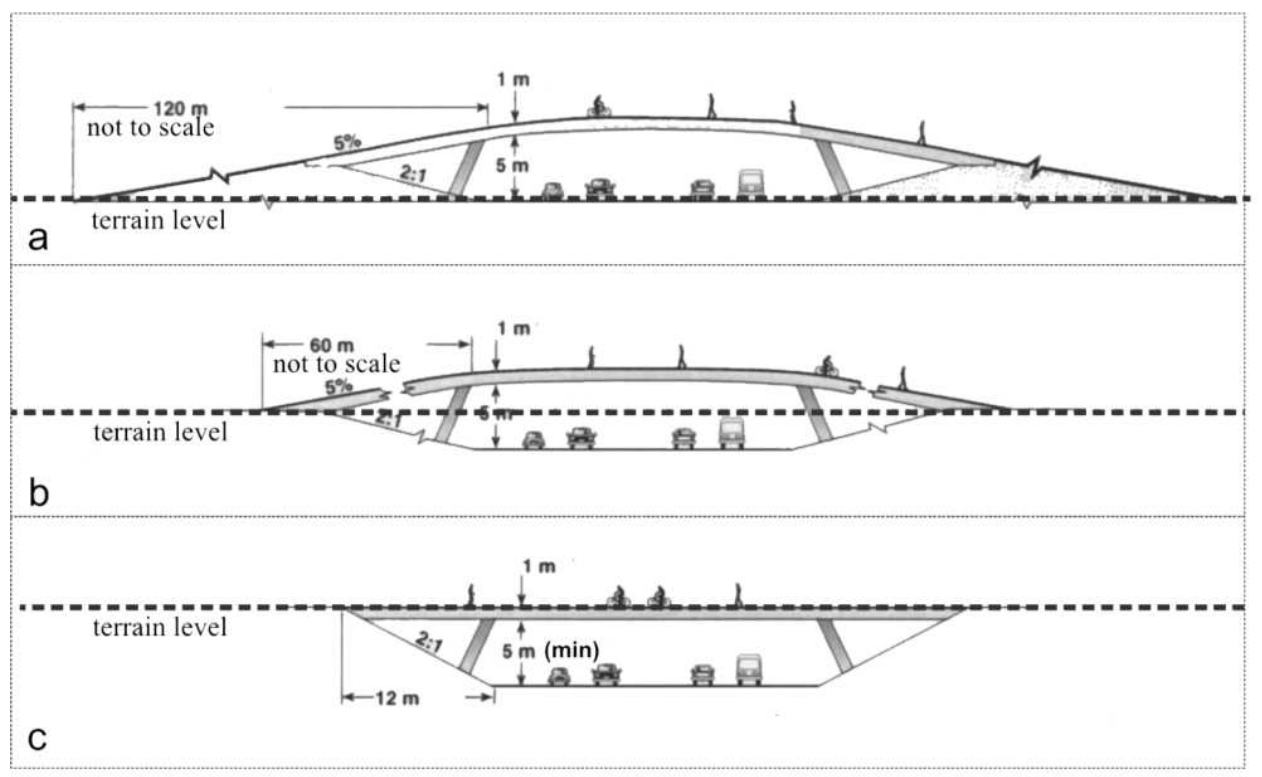

Fig. 2. Pedestrian and bicycle bridge variants depending on the level of the adjacent terrain: (a) entirely above the level of adjacent terrain; (b) at intermediate level; (c) at an adjacent terrain level [4]

(c) Инженерни науки, год. LVI, 2019, № 285

(C) Engineering Sciences, LVI, 2019, No. 2 
Pedestrian bridges and footpaths should be accessible and convenient for cyclists, mothers with prams and people with mobility disabilities. Universal access can be provided using ramps with a maximum gradient of 1:12 (5\%) whose long length provides several possible design and construction options. The different options require a different area, have a specific spatial impact and are applied depending on the specific urban conditions, Table 2, Fig. 3.

It is recommended that the ramps are divided into sections with a horizontal resting distance between them about $2 \mathrm{~m}$ long. Turns and spiral rails should not present an obstacle to cyclists. For pedestrian convenience, alternative access via stairs can be envisaged. In case of lack of ramp space on both sides of the ladder provide bicycle rails. Practice shows that elevators, escalators, etc. mechanical devices provide the necessary access for people with mobility disabilities, but due to their limited capacity, they create a feeling of discomfort for cyclists. Recommended only as an additional, not the only option to overcome the height. For cyclists, it is desirable to provide an alternative route without obstacles and stairs.

The height and construction of the handrails depends on the function of the bridge and the specific safety and aesthetic requirements in the context of the surrounding environment. For pedestrian traffic, the minimum height is 115 centimeters with intervals and openings not wider than 10 centimeters, and for bicycles -140 centimeters. Bridges over rivers and water areas provide many opportunities for creative solutions and individual design. The most severe requirements are for handrails for bridges over highways and railways they must be rigid with a minimum height of $150 \mathrm{~cm}$. Full closure additionally prevents objects from being dropped from the bridge into the traffic stream below.

TABLE 2. Ramp types and characteristics

\begin{tabular}{|l|l|l|l|}
\hline & Ramp type & Advantages & Disadvantages \\
\hline 1 & Linear & $\begin{array}{l}\text { Easy access and good condi- } \\
\text { tions for all users }\end{array}$ & $\begin{array}{l}\text { Remote start point on terrain } \\
\text { level due to great length }\end{array}$ \\
\hline 2 & Arc & $\begin{array}{l}\text { Wide turns harmoniz- } \\
\text { ing with the surrounding } \\
\text { environment }\end{array}$ & $\begin{array}{l}\text { Greater distance feeling, urging } \\
\text { users to seek a shorter route. }\end{array}$ \\
\hline 3 & Spiral & $\begin{array}{l}\text { Compact. With sufficient } \\
\text { radius ensure efficient access } \\
\text { with continuous movement }\end{array}$ & $\begin{array}{l}\text { Problems when radius and width } \\
\text { are insufficient }\end{array}$ \\
\hline 4 & Combined & $\begin{array}{l}\text { Combine the advantages of } \\
\text { linear and spiral types }\end{array}$ & Some problems in spiral part \\
\hline 5 & Segmented & $\begin{array}{l}\text { Possibility of rest in hori- } \\
\text { zontal segments }\end{array}$ & $\begin{array}{l}\text { Segments at straight angles diffi- } \\
\text { cult to turn around. }\end{array}$ \\
\hline
\end{tabular}

(c) Инженерни науки, год. LVI, 2019, № $2 \quad 86$

(C) Engineering Sciences, LVI, 2019, No. 2 


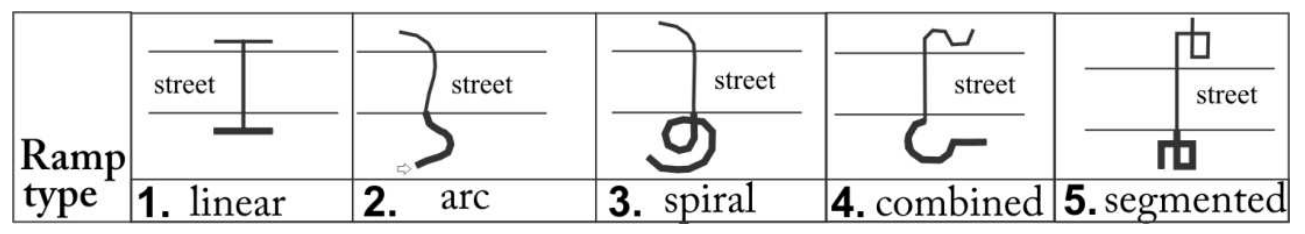

Fig. 3. Ramp types: 1 - linear; 2 - arced; 3 - spiral; 4 - combined; 5,6-segmented

\subsection{Construction requirements, materials, methods of construction}

Modern constructions, materials and technologies allowing big spans between supports, as well as the relevant technical norms and standards for bridges, continue to be the subject of research by specialists around the world and in Bulgaria. In his work [3] Iliya Ivanchev makes a thorough analysis of the historical development and the contemporary requirements for the construction systems and materials for bridges. Ivanchev classifies bridges according to their purpose and the obstacles they overcome.

Another research on the subject [5] specifies some specific construction requirements and materials for pedestrian bridges:

- Small scale and reduced capacity requirements - offering freedom for innovative solutions;

- Mandatory consideration of factors such as wind, vibration and possible collision of loads when the structure is not massive - long and relatively thin structures with a minimum number of supports;

- Minimum length, square shape constructions - allow limitation of the number of supports, improve wind resistance and driver visibility.

The cited sources, as well as numerous contemporary examples highlight the most commonly used materials for the construction of pedestrian bridges:

- Metal, Fig. 4(a). Lattice frame, beams, hollow steel profiles or composite beams, hanging constructions. Steel is the most used material in modern pedestrian bridges and passageways and allows small cross sections of the elements, economical construction, the possibility of creating attractive shapes. The steel bridges without any problem satisfy all the requirements for stability and load-bearing capacity. They are often designed as hanging, so they can achieve an exquisite appearance and visual focus on the construction.

- Wooden, Fig. 4(b). Most often are executed by elements with glued composite sections that take up the load and allow to overcoming the required distance.

(C) Инженерни науки, год. LVI, 2019, № $2 \quad 87$

(C) Engineering Sciences, LVI, 2019, No. 2 
- Reinforced concrete, Fig. 4(c). Two possible constructions: (i) monolithic allow for a variety of shapes with an elegantly constructed structure and favorable aesthetic and psychological impact, for example curved bridges, continuous smooth geometrical outlines of the lower surface of the ramps, etc.; (ii) prefabricated from pre-prepared reinforced concrete elements platforma, preloaded bearing beams with $T$ or double $T$ sections and others.
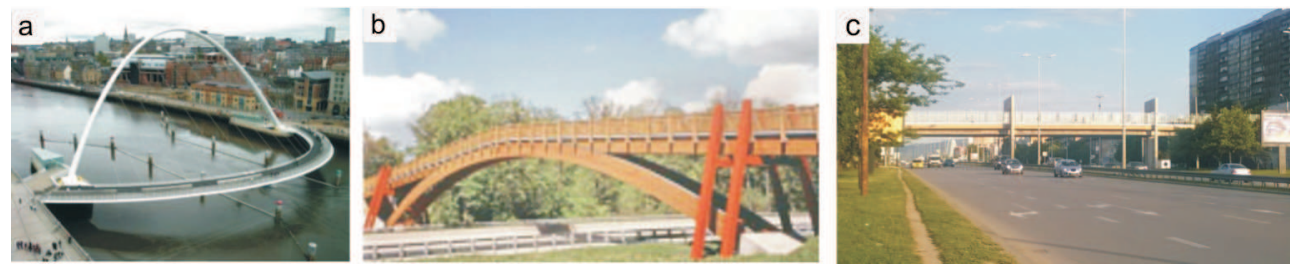

Fig. 4. Construction of pedestrian bridges: (a) metal; (b) wooden; (c) reinforced concrete

\section{EFFECTS AND RISKS OF BUILDING PEDESTRIAN AND BICYCLE FACILITIES IN THE MODERN URBAN ENVIRONMENT}

According to the author's research [6] the effects of each constructed pedestrian and bicycle facility in modern urban environments can be seen in various aspects: urban mobility; infrastructure of non-motorized traffic, spatial and architectural-artistic impact of the above-ground facilities.

One of the main tasks of the Sustainable Urban Mobility concept is limiting the dependence on motor traffic, a general reduction in its relative share, an increased culture of urban mobility. It is necessary to improve the conditions for non-motorized urban mobility; it should be possible to find convenient links for pedestrians and cyclists at the terrain level. The lack of facilities that complicate their movement stimulates the socially responsible behavior of drivers. It is an indirect prerequisite for tolerance and respect for the rights of all people in the street.

Justifying the need for overground or underground pedestrian and bicycle equipment as an integral part of the non-motorized traffic system, be consistent with the increased requirements of the citizens for the quality of the adjoining environment. Besides being infrastructure projects, modern pedestrian bridges and overpasses often perform additional functions - commercial, recreational, cultural etc. History is rich in examples of covered or fully enclosed multifunctional pedestrian bridges that have become the emblem of the

(c) Инженерни науки, год. LVI, 2019, № 288 (c) Engineering Sciences, LVI, 2019, No. 2 
city and a sign of its cultural and spatial identity. Important is also the role of urban subways in the pedestrian traffic system, which provides an excellent opportunity for the full integration of archaeological sites and other objects with cultural and historical functions.

Undoubtedly, modern pedestrian and bicycle bridges at terrain level most often have a beneficial effect on urban mobility. The strong spatial presence of many of them makes them emblematic for city objects. This is confirmed by the growing interest in the subject among experts, administrators, politicians, citizens.

The architectural and constructive solution of the bridge should stem from the nature of the environment,enriching and supplementing it, and sometimes being an accent in it. In many cases, the bridges visually improve the areas around highways, due to the contrast with adjacent facilities and low-lying surroundings. Significant influence on aesthetic qualities and favorable spatial impact of pedestrian bridges have:

- Railings, poles, handrails - their broken and attractive shapes draw pedestrians attention;

- Lighting - a powerful aesthetic impact tool that allows the bridge to accept a specific and different look, thus bringing energy and charge to the overall urban or suburban pictur;

- Landscape elements - green areas on the bridge, vertical landscaping along rails and sun shades;

- Glazed walls and coating - add an extra attraction to the urban environment.

Numerous pedestrian and bicycle bridges built over the past 10-15 years confirm the role of modern detail and all decorative and non-structural elements to increase the comfort of passing at the relatively low speed of pedestrian traffic. Due to the complexity and design specificity, the bridge is often called the "pearl of architecture" [7]. It is not by chance this is a well-known task for architects and designers from all over the world, including Santiago Calatrava, Dominique Perrault, Frank Gehry, Vito Aconchi, Alexander Chan, Bulant \& Vaytzer Studio and many others, Fig. 5. The bridge is a symbol of connection between people, movement, communication, cohesion, freedom and security. Built in the context of a specific adjoining environment, the individual design and the memorable image of the bridge have a strong impact on its future development.

\section{SOLUTIONS IN BULGARIA}

The problems discussed in the article are relevant to modern pedestrian facilities in Bulgaria, the most common being:

(c) Инженерни науки, год. LVI, 2019, № 289 (c) Engineering Sciences, LVI, 2019, No. 2 


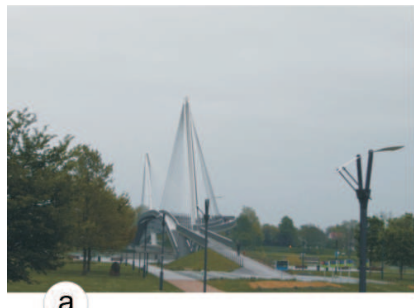

a

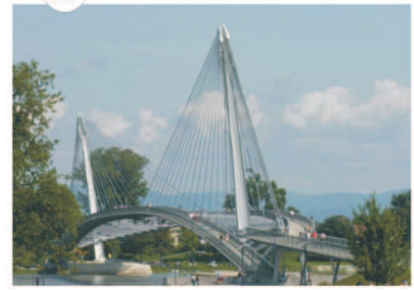

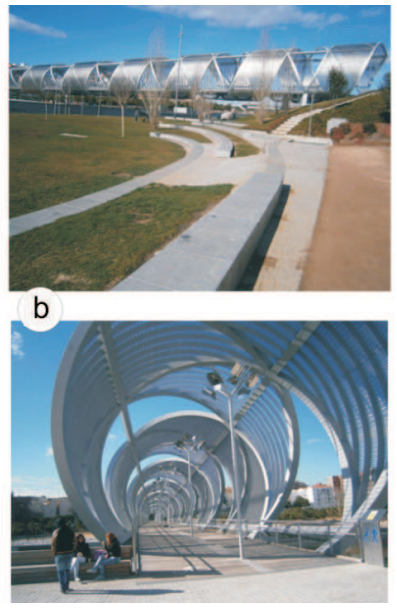

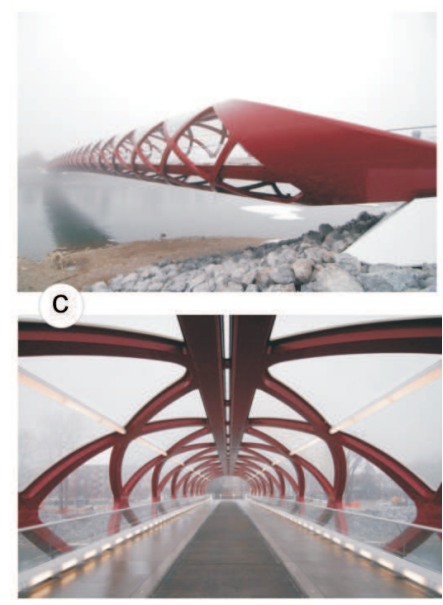

Fig. 5. Pedestrian bridges: (a) Strasbourg - Deux rives; (b) Madrid - bridge over Manzanares river, arch. Dominique Perrault; (c) Calgary bridge, arch. Santiago Calatrava

- Polyfunctional pedestrian underpasses in urban centers of large cities, successfully integrated with commercial and public transport stops, and with availability and cultural objects or archeology;

- Mono-functional underpasses for safe pedestrian crossing of streets with very intense traffic, often poorly maintained, unattractive for pedestrians and uncomfortable for cyclists;

- Overpasses for safe pedestrian crossing of city highways, built more often due to increasing traffic intensity;

- Footbridges over rivers and other obstacles.

A prevailing problem in Bulgarian practice is that the pedestrian passageways are not planned and constructed in parallel and interconnected with the transport artery, in order not to disturb the pedestrian connectivity in the city. A typical negative example are the missing pedestrian connections for the recently constructed southern arc of the ring road in Sofia. In the context of the effects and risks analyzed in the article, an important role is played by the complex assessment of the need to build the passageways, as well as the overall impact on urban mobility. In this sense, despite the ambition for innovative and attractive design, some modern implementations in our country have a contradictory impact on urban mobility and the assessment of experts and citizens for them is not unambiguous The complex overpasses in Burgas are a typical example, Fig. 6. They provide safe passage for pedestrians, but the path to walk is longer and the motor vehicle traffic is more intensive. For the reasons explained in the article, their use by cyclists is very difficult.

(c) Инженерни науки, год. LVI, 2019, № 290 (c) Engineering Sciences, LVI, 2019, No. 2 

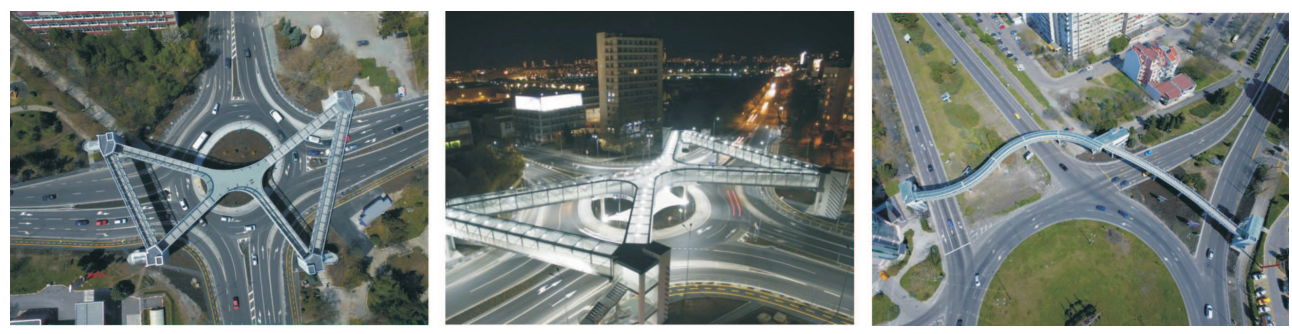

Fig. 6. Overpasses at key junctions in Burgas: left and middle - "Trapesitsa"; right - "Mirage"

The current legislature in Bulgaria [8] does not strictly regulate the necessity of passageways. Due to the poorly developed bicycle infrastructure, the city-specific combined pedestrian and bicycle bridges are still rare in Bulgarian cities.

\section{CONCLUSION}

The interdisciplinary nature of the planning and design of underground and terrestrial pedestrian and bicycle facilities requires the involvement of a wide range of specialists: architects, engineers-constructors, transport experts, urban planners, designers etc. The article provides an insight into the importance and classification of crossing facilities by two main criteria and synthesises specific principles in their planning and construction, including:

- Legislature pertaining to the necessary facilities;

- Clarification of the specific functional, normative, constructive and aesthetic requirements in designing the facilities;

- Comparative analysis of the positive and negative sides of the main groups of facilities and their elements;

- Evaluation of the effects and risks of their construction in different aspects: impact on urban mobility, spatial presence.

The modern over-ground pedestrian and bicycle facilities and city bridges as interdisciplinary objects are still a new area for Bulgarian architects with great potential for their creative expression. Good knowledge of the legal framework, functional requirements, spatial characteristics and modern practice is the basis for their effective planning, design, construction and harmonious inclusion into the urban environment.

\section{REFERENCES}

[1] Ordinance No. 2/2004 on Planning and Design of the Communication Systems of the Urban Areas, article 116.

(c) Инженерни науки, год. LVI, 2019, № 291 (c) Engineering Sciences, LVI, 2019, No. 2 
[2] Jutta Deffaner, Torben Ziel, Thomas Hefter and Christian Rudolph (Eds), Handbook on cycling inclusive planning and promotion, Capacity development material for the multiplier training within the mobile'2020 project, Frankfurt-Hamburg (2012) 115-117.

[3] I. Ivanchev, Bridges-history and present, UACG, Sofia (2014) 14-15.

[4] Rory Renfro, Portland State University Masters of Urban and Regional Planning, Field Area Paper, June (2007) 14-15.

[5] Pedestrian bridges, Infrabuild-Building, Infrastructure building VI (2012) 7.

[6] P. Sotirova, Urban mobility and transport infrastructure, UACG, Sofia (2018), ISBN 978-954-724-117-6.

[7] http://funzed.com/top-bridge-design/md-magazine.info/blog/2013/07/29/bridgesarchitecture/

[8] Ordinance No. 2/2017 on Planning and Design of the Communication Systems of the Urban Areas.

\title{
ЕФЕКТИ И РИСКОВЕ ПРИ ИЗГРАЖДАНЕ НА ПОДЗЕМНИ И НАДЗЕМНИ ПЕШЕХОДНИ И ВЕЛОСИПЕДНИ СЪОРЪЖЕНИЯ В УРБАНИЗИРАНИ ТЕРИТОРИИ
}

\author{
Петя СотировА \\ Университет по архитектура, строителство и геодезия, \\ бул. „Христо Смирненски“ № 1, 1164 София, Бглгария, \\ e-mail: petiasotirova@mail.bg
}

Резюме. Статията разглежда ролята на подземните и надземните пешеходни и велосипедни съоръжения в контекста на съвременните изисвания към средата за устойчива градска мобилност. Анализират се видовете съоръжения, факторите и условията, обуславящи техния избор, планиране и изграждане. Прилага се сравнителен анализ на подземните и надземните съоръжения по определени критерии. Систематизират се основни функцианални, конструктивни и нормативни изисквания. Обобщават се изводи за ефектите и рисковете от тяхното планиране и изграждане. Акцентира се на пространственото въздействие на надземните съръжения в специфичен урбанистичен контекст.

Ключови думи: подземни и надземни пешеходни и велосипедни съоръжения, пешеходни и велосипедни мостове, инфраструктура за устойчива градска мобилност, градска среда.

Received April 05, 2019

$\begin{array}{lll}\text { (c) Инженерни науки, год. LVI, 2019, № } 2 & 92 & \text { (c) Engineering Sciences, LVI, 2019, No. } 2\end{array}$ 